\title{
COMPARING AVERAGE AND MARGINAL TAX RATES UNDER THE FAIRTAX AND THE CURRENT SYSTEM OF FEDERAL TAXATION
}

\author{
Laurence J. Kotlikoff \\ David Rapson \\ Working Paper 11831 \\ http://www.nber.org/papers/w11831
NATIONAL BUREAU OF ECONOMIC RESEARCH
1050 Massachusetts Avenue
Cambridge, MA 02138 \\ December 2005
}

(C) 2005 by Laurence J. Kotlikoff and David Rapson. All rights reserved. Short sections of text, not to exceed two paragraphs, may be quoted without explicit permission provided that full credit, including (C) notice, is given to the source. 
Comparing Average and Marginal Tax Rates Under the FairTax and the Current System of Federal Taxation

Laurence J. Kotlikoff and David Rapson

NBER Working Paper No. 11831

December 2005, Revised November 2006

JEL No. H2

\section{ABSTRACT}

This paper compares marginal and average tax rates on working and saving under our current federal tax system with those that would arise under a federal retail sales tax, specifically the FairTax. The FairTax would replace the personal income, corporate income, payroll, and estate and gift taxes with a 23 percent effective retail sales tax plus a progressive rebate. The 23 percent rate generates more revenue than the taxes it replaces, but the rebate's cost necessitates scaling back non-Social Security expenditures to their 2000 share of GDP. The FairTax's effective marginal tax on labor supply is 23 percent. Its effective marginal tax on saving is zero. In contrast, for the stylized working households considered here, current effective marginal labor taxes are higher or much higher than 23 percent. Take our stylized 45 year-old, married couple earning $\$ 35,000$ per year with two children. Given their federal tax bracket, the claw-back of the Earned Income Tax Credit, and the FICA tax, their marginal tax is 47.6 percent. The FairTax imposes a zero marginal tax on saving meaning that reducing this year's consumption by a dollar permits one to increase the present value of future consumption by a dollar. In contrast, the existing federal tax system imposes very high marginal taxes on future consumption. For our stylized working households foregoing a dollar's consumption this year to uniformly raise consumption in all future years raises the present value of future consumption by only 45.8 to 77.4 cents, i.e., the effective marginal tax rates on uniformly raising future consumption via saving facing our households ranges from 22.6 percent to 54.2 percent. The FairTax also reduces most of our stylized households' remaining average lifetime tax rates - and, often, by a lot. Consider our stylized 30 year-old, single household earning $\$ 50,000$. The household's average remaining lifetime tax rate under the current system is 21.1 percent. It's 16.2 percent under the FairTax.

Laurence J. Kotlikoff

Department of Economics

Boston University

270 Bay State Road

Boston, MA 02215

and NBER

kotlikoff@bu.edu

David Rapson

270 Bay State Rd

Department of Economics

Boston University

Boston, MA 02215

rapson@bu.edu 


\section{Executive Summary}

The FairTax is a proposal to replace the federal personal income tax, the federal corporate income tax, the federal payroll (FICA) tax, the federal estate tax, the federal gift tax, and the federal generation-skipping tax with a federal retail sales tax, assessed at a single rate. The FairTax also provides a rebate to each household based on its demographic composition. The rebate is set to ensure that households living at or below the poverty line pay no taxes on net.

This paper compares average and marginal labor income and saving tax rates under the current federal tax system and the FairTax. As specified in H.R. 25/S. 25, the legislation that would implement the reform, the FairTax's tax rate is 23 percent. This tax rate is measured on a taxinclusive basis, meaning that a dollar's expenditure would yield 77 cents in consumption after payment of the retail sales tax.

Although Gale (2005) questions whether a 23 percent tax-inclusive rate would suffice to maintain real federal spending and also cover the FairTax rebate, a recent analysis by Bachman, Haughton, Kotlikoff, Sanchez-Penalver, and Tuerck (2006) based on CBO 2007 projections indicates that less than a 3 percent scale-back of non-Social Security real federal expenditures would be needed to accommodate a 23 percent FairTax rate. As a share of GDP, these expenditures have risen by over 20 percent since 2000 .

In asserting that a real revenue-neutral 23 percent FairTax is feasible, Bachman, et al. (2006) assume that the revenue losses due to evasion and avoidance under the FairTax will be no greater than those already incumbent in NIPA measures of household consumption. In so doing, Bachman, et al. (2006) may overstate the FairTax revenue base. On the other hand, Bachman, et al. (2006) likely understate the revenue base in ignoring the FairTax's general equilibrium, macroeconomic feedback effects. Indeed, as discussed in Kotlikoff (2005), introducing the FairTax would likely raise real wages by 19 percent over the course of the century relative to what technological improvements would otherwise generate. On the other hand, Kotlikoff's paper shows that the aging of society, interacting with our Social Security and government health care systems, will place significant stresses on the nation's finances. And the ability of the government under a FairTax to maintain the tax system's tax rate at 23 percent or, indeed, even lower, will depend critically on reforming these major entitlement programs.

Households finance their current and future expenditures on consumption based on their current wealth and their current and future labor earnings. Hence, taxing consumption expenditures is effectively equivalent to taxing existing wealth and labor income. Given its 23 percent rate, the FairTax would effectively tax both existing wealth and current and future labor earnings at a 23 percent rate.

As shown here, current total effective federal marginal tax rates on labor supply appear to be either higher or much higher for almost all American households than they would be under the FairTax. The current system's marginal wage tax rate exceeded the FairTax's 23 percent marginal rate for all of the 42 single and married stylized households we considered. 
For some low- and middle-income households, the marginal tax on working under our current tax system is more than twice the 23 percent FairTax rate! Take, as an example, a middle-aged married couple earning \$30,000 per year with two children. Given the level of their federal marginal tax bracket, their loss, at the margin, of the Earned Income Tax Credit from earning extra income, and their exposure to marginal FICA taxation, their current total marginal effective tax on earning an extra dollar is 47.6 percent!

Since the FairTax taxes consumption at the same rate no matter when it occurs, it imparts no incentive to consume now as opposed to later and, thus, no disincentive to save. In economic terms, the FairTax's marginal effective tax rate on saving is zero. In contrast, the existing federal tax system imposes very high marginal effective tax rates on saving. For the 42 households considered here, marginal effective tax rates on saving range from 22.6 percent to 54.2 percent.

In addition to imposing, in almost all cases, much lower marginal taxes on working and, in all cases, dramatically lower marginal taxes on saving, the FairTax imposes much lower average taxes on working-age households than does the current system. The FairTax broadens the tax base from what is now primarily a system of labor income taxation to a system that taxes, albeit indirectly, both labor income and existing wealth. By including existing wealth in the effective tax base, much of which is owned by rich and middle-class elderly households, the FairTax is able to tax labor income at a lower effective rate and, thereby, lower the average lifetime tax rates facing working-age Americans.

Consider, as an example, a single household age 30 earning $\$ 50,000$. The household's average tax rate under the current system is 21.1 percent. It's 13.5 percent under the FairTax. Since the FairTax would preserve the purchasing power of Social Security benefits and also provide a tax rebate, older low-income workers who will live primarily or exclusively on Social Security would be better off. As an example, the average remaining lifetime tax rate for an age 60 married couple with $\$ 20,000$ of earnings falls from its current value of 7.2 percent to -11.0 percent under the FairTax. As another example, compare the current 24.0 percent remaining lifetime average tax rate of a married age 45 couple with $\$ 100,000$ in earnings to the 14.7 percent rate that arises under the FairTax.

The FairTax not only lowers remaining average lifetime net tax rates. It also maintains and, indeed, enhances overall progressivity in the tax system. Consider middle-aged married households. The FairTax average lifetime tax rate is very low - only 1.5 percent - for the couple with $\$ 20,000$ in annual earnings, and much higher - 20.5 percent - for the couple with $\$ 500,000$ in annual earnings. The reduction in the tax rate at low earnings is proportionately much greater at the low end of the earnings distribution than at the high end. In switching to the FairTax, the \$20,000-earning couple experiences an 86 percent cut in its average tax rate, whereas the \$500,000-earning couple experiences a 42 percent cut.

The current federal fiscal system is highly complex. Understanding its work and saving incentives for any given household requires very sophisticated software - software that deals with (a) all major provisions of the federal income tax, including the Earned Income Tax Credit, the child tax credit, 
the alternative minimum tax, Social Security benefit taxation, the decision to itemize deductions, the indexation of tax brackets, exemptions, and standard deductions, and the interaction of the federal income tax with each state's personal income tax, (b) the complex determination of Social Security benefits, which includes the calculation of primary insurance amounts, early retirement benefit reductions, delayed retirement credits, the recomputation of benefits associated with earnings after benefits have begun, the earnings test, family benefit maxima, and the scheduled rise in the age of normal retirement, (c) the payroll tax, including its separate employer and employee components, its interaction with federal income taxation, and the projected increase in the covered earnings ceiling, and (d) the reduction in after-tax returns arising from the U.S. corporate income tax.

Following Gokhale, Kotlikoff, and Sluchynsky (2002), the method used here to study average and marginal taxes under the existing federal tax system is to run a set of stylized households through ESPlanner $^{T M}$ (Economic Security Planner ${ }^{\mathrm{TM}}$ ), a personal financial planning software program. The program, which was co-developed by myself and Dr. Jagadeesh Gokhale, determines a household's highest sustainable living standard and the amount of saving, spending, and life insurance needed to preserve that living standard through time. In "smoothing" a household's living standard, the software ensures that the household never exceeds its borrowing limit (which is typically zero).

In forming its recommendations, ESPlanner makes highly detailed, year-by-year federal and state income tax and Social Security benefit calculations, which take into account all the aforementioned tax and benefit provisions as well as a host of others. Because it focuses on lifetime planning, ESPlanner considers how current work and saving decisions affect not just current taxes and Social Security benefits, but also all future taxes and Social Security benefits. This life-cycle/dynamic element is critical to understanding the size of effective marginal taxes. The reason is simple. Earning or saving another dollar this year alters not just this year's taxes and, potentially, Social Security benefits, but also, potentially, all future taxes and Social Security benefits. Ignoring any of those future tax and benefit provisions can seriously distort the measurement of the true gain from extra work or saving.

Economists measure the gain from extra work or saving in terms of consumption. The gain from extra work is typically measured in terms of its maximum impact on current consumption. Thus, if a worker earns an extra $\$ 100$ this year permitting this year's consumption to rise, at most, by $\$ 50$, we say the worker faces a 50 percent marginal tax on his or her labor supply.

The gain from extra saving is typically measured in terms of the impact on future consumption of forgoing a fixed amount of current consumption. In the absence of any effective marginal tax on saving, reducing current consumption by, say, \$100 would lead to an increase in future consumption, measured in present value, of $\$ 100$. If future consumption, measured in present value, rises by only $\$ 50$, we say that the saver faces a 50 percent marginal tax on saving.

ESPlanner is ideally suited to measuring these tax rates on working and saving thanks to its underlying consumption-smoothing algorithm and its standard of living index. These features allow users to specify if and how they'd like their living standard to change in the future. The program can, in effect, be told to spend on current consumption and only on current consumption all the net 
proceeds arising from additional current earnings. (Net proceeds references the additional current earnings themselves less any increase in current and future taxes plus any increase in current and future Social Security benefits, where changes in future taxes and Social Security benefits are measured in present value.) And in measuring the marginal effective tax on saving, the program can, in effect, be told to spend the proceeds of additional current saving so as to uniformly raise consumption in all future periods. 


\section{Introduction}

With over 17,000 pages and counting, the U.S. federal tax law is anything but straightforward. Nor is it cheap to use. The annual cost of administering, enforcing, and complying with federal personal and business taxes runs, according to the GAO (2005), in the hundreds of billions of dollars. The GAO also estimates that the annual efficiency loss arising from the disincentives of the current tax system ranges from 2 to 5 percent of GDP.

The cost is not simply economic. A small army of well educated and highly talented lawyers, accountants, and auditors wastes every hour of the working day coping with the U.S. tax code instead of engaging in work of real social and, presumably, psychological value.

With all this effort, one might expect real understanding of how our tax system works. But the system is so complex that no one can claim to fully comprehend its provisions, incentives, or the degree to which it is redistributing income across the population. Indeed, the tax code has so befuddled and clogged our brains that we're virtually flying blind when it comes to managing our fiscal affairs.

This is particularly true when it comes to the structure of work and saving incentives. Calculating total effective marginal tax rates on these economic choices is no minor task. Consider, for example, trying on one's own to determine the net marginal effective tax rate facing low-income workers on an extra dollar of earnings. Doing so necessitates considering the employer and employee portions of the payroll tax, the federal income tax, including the Earned Income Tax Credit, the effect of extra current earnings on future Social Security benefits, the extent of future income taxation of future Social Security benefits, the interaction of the payroll tax and the federal income tax, and the procedure for calculating the present value of changes in future Social Security benefits net of changes in future federal income taxes.

Millions of Americans understand the ingredients used to make our tax code sausage and yearn for a wholesale reform that would leave us with a simple, fair, transparent, and easy to administer tax system. There are several such candidates, including a value-added tax (VAT), a flat tax, and a federal retail sales tax. Of these the most straightforward is the federal retail sales tax, which taxes purchases of consumption goods and services at a single rate. The VAT and flat taxes would also tax consumption, albeit indirectly and only if they are implemented without special transition rules that exempt from taxation the sale of existing capital goods.

For economists, shifting from our current system, which primarily taxes labor income, to taxing consumption has a number of interesting and important features. First, it broadens the effective tax base from primarily current and future labor income to current and future labor income plus existing wealth. The reason the consumption tax base effectively includes these two components is that current and future consumption purchases are financed by current and future labor earnings plus existing wealth. And taxing these purchases is effectively equivalent to taxing what is used to pay for them. 
Second, because it effectively taxes existing wealth, taxing consumption penalizes the rich, potentially enhancing overall tax progressivity. Even if the rich save their existing wealth and bequeath it, plus any accrued capital income, their wealth still ends up getting hit with a tax once their children or other heirs spend these resources. The present value of the taxes paid on the consumption financed by the bequeathed wealth plus the accrued income on that wealth is the same as taxing the wealth immediately (i.e., spending all the wealth immediately and paying consumption taxes right away).

Third, since the elderly have very little labor income and own roughly two-thirds of the nation's wealth, switching to a consumption tax lifts some of the burden of taxation from today's and tomorrow's workers and shifts it onto retirees. While current and future workers are still effectively taxed on their labor earnings when they spend them on consumption, the effective tax rate on those earnings is lower than under the existing system. This is thanks to the base broadening arising from the switch to consumption taxation, viz., the inclusion of existing wealth to the effective tax base.

Many would think that hitting the poor elderly with a higher tax burden is unfair and immediately discount a consumption tax on that basis. But under our current Social Security system the poor elderly, whose income comes almost exclusively from that source, would be totally unaffected by a consumption tax. The reason is that the system's annual inflation indexation guarantees the real purchasing power of recipients' benefits. To see this, consider what would happen were a retail sales tax adopted. Any increase in prices associated with the sales tax would lead to equal percentage increases in Social Security benefits.

Fourth, switching our federal tax system in its entirety to consumption taxation would permit reducing effective marginal taxes on labor supply (due to the base broadening). Doing so would also eliminate entirely the marginal taxation of saving. Since economic distortions - what economists call the excess burden of taxation - depend in a non-linear manner on the level of effective marginal tax rates, reducing these tax rates holds the promise of significantly reducing economic inefficiency.

Fifth, a large volume of simulation studies starting with Summers (1981) and Auerbach and Kotlikoff (1987) show that switching to consumption taxation can dramatically raise a nation's national saving, domestic investment, capital per worker, labor productivity, and real wages. The increase in national saving reflects the elimination of the tax on saving as well as the redistribution away from older spenders to younger savers. As shown in Gokhale, Kotlikoff, and Sabelhaus (1996), America's elderly have much higher propensities to spend, when properly measured, than do the young and, certainly, future generations.

For the U.S. the predicted increase in domestic investment from switching to consumption taxation occurs whether or not one views the economy as open or closed, at the margin, to international capital flows. If an economy is closed, all national saving is invested at home, so every extra dollar in national saving translates directly into an extra dollar of domestic investment. If an economy is open, domestic investment is determined by how much savers in the U.S. and abroad want to invest in the country. But if, as in the U.S., the wholesale switch to consumption taxation would entail the elimination of a corporate income tax whose marginal effective rate is quite high (the U.S. value is 
very close to the statutory 35 percent rate), both domestic and foreign savers will find investing in the zero-corporate tax country highly attractive.

The extent to which U.S. tax reform delivers the saving, domestic investment, income, equity, and efficiency gains that appear available in moving to consumption taxation depends, of course, on the degree to which the reform actually taxes consumption. The FairTax, awaiting passage in Congress as H.R. 25/S. 25, does tax consumption. Indeed, except for imputed rent on existing housing and durables, the FairTax taxes all consumption (including rents on housing, new rental and owner occupied housing, and new durables). And it does so directly via a federal retail sales tax.

The FairTax would replace the federal personal income tax, the federal corporate income tax, the federal payroll (FICA) tax, the federal estate tax, the federal gift tax, and the federal generationskipping tax with a federal retail sales tax, assessed at a single rate. The FairTax also provides a rebate to each household based on its demographic composition. The rebate is set to ensure that households living at or below the poverty line would pay no taxes on net.

This paper compares average and marginal tax rates on working and saving under the current system with those that would arise under the FairTax. As specified in H.R. 25/S. 25, the legislation that would implement the reform, the FairTax's tax rate is 23 percent. This tax rate is measured on a tax-inclusive basis, meaning that a dollar's expenditure would yield 77 cents in consumption after payment of the retail sales tax.

Although Gale (2005) questions whether a 23 percent tax-inclusive rate would suffice to maintain real federal spending and also cover the FairTax rebate, a recent analysis by Bachman, Haughton, Kotlikoff, Sanchez-Penalver, and Tuerck (2006) based on CBO 2007 projections indicates that less than a 3 percent scale-back of non-Social Security real federal expenditures would be needed to accommodate a 23 percent FairTax rate. As a share of GDP, these expenditures have risen by over 20 percent since 2000 .

In asserting that a real revenue-neutral 23 percent FairTax is feasible, Bachman, et al. (2006) assume that the revenue losses due to evasion and avoidance under the FairTax will be no greater than those already incumbent in NIPA measures of household consumption. In so doing, Bachman, et al. (2006) may overstate the FairTax revenue base. On the other hand, Bachman, et al. (2006) likely understate the revenue base in ignoring the FairTax's general equilibrium, macroeconomic feedback effects. Indeed, as discussed in Kotlikoff (2005), introducing the FairTax would likely raise real wages by 19 percent over the course of the century relative to what technological improvements would otherwise generate. On the other hand, Kotlikoff's paper shows that the aging of society, interacting with our Social Security and government health care systems, will place significant stresses on the nation's finances. And the ability of the government under a FairTax to maintain the tax system's tax rate at 23 percent or, indeed, even lower, will depend critically on reforming these major entitlement programs.

As mentioned, the effective tax base of a consumption tax is existing wealth and current and future labor income. Given its 23 percent rate, the FairTax would effectively tax both existing wealth and 
current and future labor earnings at a 23 percent rate.

As shown here, current total effective federal marginal tax rates on labor supply appear to be either higher or much higher for almost all American households than they would be under the FairTax. The current system's marginal wage tax rate exceeded the FairTax's 23 percent marginal rate for all of the 42 single and married stylized households we considered.

For some low- and middle-income households, the marginal tax on working under our current tax system is more than twice the 23 percent FairTax rate! Take, as an example, a middle-aged married couple earning \$30,000 per year with two children. Given their federal tax bracket, their loss, at the margin, of the Earned Income Tax Credit from earning extra income, and their exposure to marginal FICA taxation, their current marginal tax is 47.6 percent!

Since the FairTax taxes consumption at the same rate no matter when it occurs, it imparts no incentive to consume now as opposed to later and, thus, no disincentive to save. In economic terms, the FairTax's marginal effective tax rate on saving is zero. In contrast, the existing federal tax system imposes very high marginal effective tax rates on saving. For the 42 households considered here, marginal effective tax rates on saving range from 22.6 percent to 54.2 percent. This means that when the 42 households we consider reduce their current consumption by $\$ 1.00$, their future consumption goes up by only 77.4 cents to 45.8 cents, when measured in present value. Under the FairTax, giving up $\$ 1.00$ of current consumption permits an increase in future consumption equal to the full \$1.00, when measured in present value.

In addition to imposing, in almost all cases, much lower marginal taxes on working and, in all cases, dramatically lower marginal taxes on saving, the FairTax imposes much lower average taxes on working-age households than does the current system. The FairTax's reduction in average tax rates on the working age population reflects the broadening of the tax base from what is now primarily a system of labor income taxation to a system that taxes, albeit indirectly, both labor income and existing wealth. Consider, as an example, a single age 30 household earning \$50,000. The household's average tax rate under the current system is 21.1 percent. It's 13.5 percent under the FairTax.

Since the FairTax would preserve the purchasing power of Social Security benefits and also provide a tax rebate, older low-income workers who will live primarily or exclusively on Social Security would be better off. As an example, the average remaining lifetime tax rate for an age 60 married couple with $\$ 20,000$ of earnings falls from its current value of 7.2 percent to -11.0 percent under the FairTax. As another example, compare the current 24.0 percent remaining lifetime average tax rate of a 45-year-old married couple with $\$ 100,000$ in earnings to the 14.7 percent rate that arises under the FairTax.

The current federal fiscal system is highly complex. Understanding its work and saving incentives for any given household requires very sophisticated software - software that deals with (a) all major provisions of the federal income tax, including the Earned Income Tax Credit, the child tax credit, the alternative minimum tax, Social Security benefit taxation, the decision to itemize deductions, the 
indexation of tax brackets, exemptions, and standard deductions, and the interaction of the federal income tax with each state's personal income tax, (b) the complex determination of Social Security benefits, which includes the calculation of primary insurance amounts, early retirement benefit reductions, delayed retirement credits, recomputation of benefits, the earnings test, family benefit maxima, and the scheduled rise in the age of normal retirement, (c) the payroll tax, including its separate employer and employee components, its interaction with federal income taxation, and the projected increase in the covered earnings ceiling, and (d) the reduction in after-tax returns arising from the U.S. corporate income tax.

The method used here to study average and marginal taxes under the existing federal tax system is to run a set of stylized households through ESPlanner ${ }^{T M}$ (Economic Security Planner ${ }^{\mathrm{TM}}$ ), a personal financial planning software program. The program, which was co-developed by myself and Dr. Jagadeesh Gokhale, smooths households' living standards to the maximum extent possible without violating the households' borrowing limits.

In performing its consumption smoothing, ESPlanner makes highly detailed, year-by-year federal and state income tax and Social Security benefit calculations, which take into account all the aforementioned tax and benefit provisions as well as a host of others. Because it focuses on lifetime planning, ESPlanner considers how current work and saving decisions affect not just current taxes and Social Security benefits, but also all future taxes and Social Security benefits. This lifecycle/dynamic element is vital to understanding the size of effective marginal taxes. The reason is simple. Earning or saving another dollar this year alters not just this year's taxes and, potentially, Social Security benefits, but also, potentially, all future taxes and Social Security benefits. Ignoring any of those future tax and benefit changes can seriously distort the measurement of the true gain from extra work or saving.

This paper proceeds by discussing the measurement of effective marginal tax rates on working and saving. It then describes ESPlanner in some detail. Next it compares, for a set of stylized households, total effective marginal and average tax rates under the current system with those that would arise under the FairTax. The final section summarizes and concludes.

\section{Measuring Effective Tax Rates}

Economists measure the gain from extra work or saving in terms of consumption. The gain from extra work is typically measured in terms of its maximum impact on current consumption. Thus, if a worker earns an extra $\$ 100$ this year permitting this year's consumption to rise, at most, by $\$ 50$, we say the worker faces a 50 percent marginal tax of his or her labor supply.

The gain from extra saving is typically measured in terms of the impact on future consumption of forgoing a fixed amount of current consumption. Consider, for example, a two-period (youth and old age) framework. In the absence of any effective marginal tax on saving, reducing current consumption when young by $\mathrm{X}$ would lead to an increase in consumption when old, measured in present value, of exactly $\mathrm{X}$. If consumption when old, measured in present value, rises by only onehalf of $\mathrm{X}$, we can say that the saver faces a 50 percent marginal tax on saving. More precisely, we 
say that the tax on future consumption is 100 percent since the price, measured in present value, of consuming $\mathrm{X}$ when old has risen from $\mathrm{X}$ to $2 \mathrm{X}$.

ESPlanner is ideally suited to measuring these tax rates on working and saving thanks to its underlying consumption-smoothing algorithm and its standard of living index feature, which allows users to specify if and how they'd like their living standard to change in the future. The program can, in effect, be told to spend on current consumption and only on current consumption all the net proceeds arising from additional current earnings. (Net proceeds means the additional current earnings themselves less any increase in current and future taxes plus any increase in current and future Social Security benefits, where changes in future taxes and Social Security benefits are measured in present value.) And in measuring the marginal effective tax on saving, the program can, in effect, be told to spend the proceeds of additional current saving in any particular future year one wants or, if one wants, in all future years on a uniform basis.

\section{Borrowing Constraints}

In running ESPlanner one is free to specify the maximum amount that can be borrowed to smooth one's living standard. If the household in question does not need to borrow beyond its borrowing limit, which can, and typically is, set to zero, the program will generate a spending, saving, and insurance plan that entails the household having the exact same living standard through time as well as for all years following the death of the household head or spouse/partner. If, on the other hand, achieving a perfectly smooth living standard is not possible without exceeding the household's borrowing limit, the program will determine the smoothest possible living standard path. But this will involve a rise at some point over time in the household's living standard.

Take, as an example, a household age 45 that earns $\$ 50,000$ a year, has very little savings, but expects to inherit $\$ 1$ million at age 65. If the household can't borrow against the $\$ 1$ million, it will have to live with a lower living standard prior to age 65 and a higher one thereafter. ESPlanner smooths the living standard prior to age 65 at the highest level possible so that the household can afford the same standard right up to age 65, and it also smooths the living standard for all years at and after age 65. So there is a jump up in the household's living standard at age 65 from a previously constant living standard level to a higher constant level.

Depending on the particular pattern of future income and non-smoothable expenditures (e.g., mortgage payments), households may have multiple periods of liquidity constraints over their lifetimes. In this case, ESPlanner will raise their living standard through time, smoothing their living standard perfectly within each liquidity-constrained interval.

This discussion is important for considering the calculation of effective marginal taxes. To see this, consider the decision by a 35-year-old to work more in the current year and earn, say, an extra $\$ 1000$. Assume, as is likely, that this decision raises the 35-year-old's future Social Security benefits. If, because of his borrowing limit, the 35-year-old cannot access that benefit increase in terms of his current spending (his spending at age 35), we can no longer only describe his effective marginal tax rate in terms of its impact on his current spending. We'd have to say that earning an 
extra $\$ 1000$ at age 35 affects not just current but also future spending. The result would be a complicated description of effective marginal taxes.

To avoid this problem we set the borrowing limit on ESPlanner high enough to ensure that the stylized households we consider are able to smooth their living standard perfectly over their lifetimes. In addition, to ensure that all the additional spending power from additional current-year earnings is concentrated solely on current-year spending, we ran ESPlanner in the following manner. First we ran the program with earnings at their initially specified levels and recorded the level of 2005 consumption. We then ran the program again assuming a higher level of earnings in 2005, keeping earnings in all future years unchanged.

In running the program the second time, we also lowered the program's standard of living index for all post-2005 years to ensure that consumption levels after 2005 would remain at their previous values and, consequently, all of the additional purchasing power from the higher 2005 earnings would be spent solely on higher 2005 consumption. This required some iteration to get the right living standard index adjustments. The ratio of the change in 2005 consumption across the initial and new runs of ESPlanner to the change in 2005 earnings provides the effective marginal tax rates on working reported below.

\section{ESPlanner's Standard of Living Index}

Let me digress to clarify how the program's standard of living index works. The index is fixed at 100 for the current year and can be separately adjusted up or down from 100 for all future years. If, for example, one sets the living standard index to 115 for, say, the years 2020 and beyond, the program will know to raise the household's living standard by 15 percent starting in 2020 relative to the living standard in 2005. Since the household's resources (assets, income, pensions, etc.) are not changed when one changes the index, the program will lower the absolute living standard prior to 2020 (and thus its pre-2020 recommended consumption spending) and raise it starting in 2020 (and, thus, its recommended level of consumption spending in 2020 and thereafter).

As another example, consider setting the living standard index to 95 for all years starting in 2006. The program will then know to lower the household's living standard by 5 percent in each year starting with 2006 relative to the living standard in 2005. Again, making this change in the living standard index leaves current and future resources unchanged. So the program will raise the household's absolute living standard in 2005 (and, thus, its 2005 recommended consumption spending) and lower its absolute living standard starting in 2006 (and, thus, its recommended consumption spending for 2006 and beyond).

Now consider changing the household's resources at the same time you change the living standard index from its default values of 100 for 2005 and all future years. For example, consider uniformly lowering the value of the post-2005 living standard index to 95, and at the same time increasing 2005 earnings by, say, $\$ 1000$. In this case, the program will still end up with a 2005 living standard that is 5 percent higher than after 2005, but the absolute post-2005 living standard will not necessarily be lower than it was initially since there are now extra resources for the program to 
spend. If one sets just the right values of the post-2005 index, which may be lower or higher than 95, one can keep post-2005 consumption at precisely its initial values and, therefore, concentrate all additional spending just on 2005.

But if future Social Security benefits are higher, how does the program keep future spending from being higher as well? The answer is that it effectively borrows against those future higher Social Security benefits (net of any changes in taxation of those benefits), leaving the household in old age with higher Social Security benefits, but also lower assets than would otherwise be the case.

The reason we say that all the additional purchasing power in these calculations is spent on additional 2005 consumption is that the households we consider not only end up consuming the same amounts every year after 2005, but also end up with no remaining assets or liabilities at the end of life. In short, the households die broke. Consequently, every penny that can be spent on additional 2005 consumption without altering future consumption and future living standards is, indeed, being spent. So the change in 2005 consumption takes into account the impact of higher earnings not just on current taxes, but also on future Social Security benefits as well as future taxes of those benefits. And, to repeat, a comparison of the increase in 2005 earnings with the increase in 2005 consumption provides the measure of the effective marginal tax on working.

\section{Calculating Effective Marginal Taxes on Saving}

Unlike the calculation of effective marginal tax rates on labor supply, when there is more than one period (more than one future year) in which to consume, there is no standard definition of the effective tax rate on saving. One could, for example, consider how much reducing this year's consumption by, say, $\$ 100$ will increase the present value of future consumption spending assuming the additional future spending power is all allocated to next year's consumption. Alternatively, one could allocate all the future spending power to consumption 10 years out, or 20 years out, or in any future year one chooses. One could also spread the extra spending power uniformly over all future years. Each such choice will generate a different measure of the effective tax rate. The reason is that the longer one pushes out the allocation of the extra spending power, the higher the effective tax rate will be thanks to the nature of compounding.

To understand more clearly what is going on, note that the underlying goods that households are choosing when they make their work and saving decisions are really how much leisure and consumption to purchase in the current year as well as in each future year. These fundamental goods have prices in the absence of any taxes, and they have different prices in the presence of taxes. The difference between the prices of leisure and consumption with and without taxes determines the tax rate on these underlying goods.

Consider what I've been calling the tax on work. In fact, the tax on work is really telling us about the price of current leisure. If a worker can earn $\$ 20$ an hour with no taxes, but only $\$ 10$ an hour with taxes, the tax system has lowered the price of leisure by a half - from a loss of $\$ 20$ of consumption per hour of leisure to a loss of only $\$ 10$ of consumption per hour of leisure. So the tax on work corresponds to a negative tax - a subsidy - on leisure. In this case, the subsidy rate is 50 
percent.

Now consider consumption in future years. Take consumption in 2010 as an example. We measure the price of consumption in 2010 in terms of the sacrifice in current (2005) consumption needed to raise future consumption by $\$ 1.00$. To make this concrete, let the pre-tax rate of return be 5 percent. In this case, the price, in the absence of taxes, of consuming $\$ 1.00$ more in 2010 is 78.3 cents measured in terms of current consumption. The reason is that one can invest 78.3 cents for 5 years at 5 percent starting in 2005 and end up with \$1.00 in 2010.

If the price of consuming a dollar in five years is that you have to give up 78.3 cents now, what would the price be if you were to face taxes on the return to saving and the after-tax return was not 5 percent, but only 3 percent? The answer is 86.3 cents because investing 86.3 cents for five years at a 3 percent return yields $\$ 1.00$.

So with taxes, consuming that dollar in five years costs 86.3 cents today in the presence of taxes, but only 78.3 cents in the absence of taxes. The difference in these two numbers indicates the effective tax rate on consumption five years from now. Indeed, since 86.3 divided by 78.3 equals 1.10 , we can say that the tax system is imposing a 10 percent tax on consuming five years from now.

If we do the same calculations with respect to consuming not five years from now, but 20 years from now, the no-tax price of consuming \$1.00 in 20 years is 37.7 cents. But it's 55.4 cents in the presence of taxes. The ratio of 55.4 to 37.7 indicates that the tax rate on consuming 20 years from now is 46.9 percent. Clearly, which year in the future one considers makes a big difference to one's measure of the size of the incentive to consume now (to dissave) rather than to consume in the future (to save).

The calculations presented show the effective tax rate on saving assuming that the reduction in 2005 spending is allocated uniformly to all future periods such that the living standard in all future periods rises by the same percentage. To effect this outcome in ESPlanner, we simply raised the living standard index for all years from 2006 on by 10 percent and compared the increase in the present value of consumption spending from 2006 on with the reduction in consumption spending in 2005. The discount rate used to determine the present value change in future consumption, all measured in 2005 dollars, is 7.0 percent, which is the assumed pre-tax real rate of return. This pre-tax return is the return one would receive before the application of any federal personal or corporate income taxes.

In running ESPlanner we assume that the effective marginal federal corporate tax rate equals 35 percent, which happens to be the statutory rate. Since 65 percent of 7 percent is 4.55 percent, we assume that the real return to households is 4.55 percent. Coupling this assumption with my 3.0 percent inflation rate assumption leads me to enter a nominal return of 7.69 percent in running the program. ${ }^{1}$

\footnotetext{
${ }^{1}$ Note that the nominal interest rate equals [(1 plus the inflation rate) times (1 plus the real rate)] minus 1.
} 
In this and all other calculations carried out for this study, we assumed that the stylized households being examined live in a state with no state personal income or corporate income taxes. The reason is that the goal of this paper is to compare total effective federal marginal and average tax rates in our current tax regime with the corresponding rates that would arise under the FairTax. Including state income taxes in the analysis would muddy this comparison because of the interaction of state and federal income taxes. Indeed, because of this interaction, it's not possible to clearly distinguish federal from state marginal taxation. To see this, consider a New York household that increases its 2005 earnings by $\$ 1000$. This raises the household's federal personal income taxes as well as its New York state income taxes. But the extent to which the federal taxes rise depends on New York state income taxes, since state income taxes are deductible from the federal income tax provided the household itemizes its deductions. One could just as well say that the reduction in federal income taxes arising from the payment of state income taxes reflects a lower federal marginal rate or a lower state marginal rate. Similar problems of distinguishing federal from state marginal taxation of saving arise in the presence of state corporate income taxation.

\section{Calculating Average Remaining Lifetime Tax Rates}

In addition to comparing marginal incentives to work and save under the current federal tax system and the FairTax, this paper seeks to compare overall fiscal burdens by examining average remaining lifetime net tax rates under the two systems. The term "remaining lifetime" simply refers to the household's remaining years of life. So the calculations are prospective, rather than retrospective. They are also looking at all future federal tax payments net of Social Security benefits.

We define the average remaining lifetime tax rate as (A-B)/A, where $A$ is the present value of spending, defined here as consumption and non-fungible spending (college tuition, mortgage and other housing expenses, and life insurance premiums) in the absence of any federal taxation and B is the present value of spending under the tax regime in question. The term spending, as used here, does not include payment of FairTax. Note that in the absence of any federal taxation, A is also equal to the present value of the household's remaining lifetime resources - its current assets plus the present value of its current and future labor earnings and current and future Social Security benefits. So the average tax rates being computed here are measured relative to the most comprehensive resource measure available. In forming these present values, we discount at the pretax (including pre-corporate tax) rate of return of 7.0 percent. In words, this ratio indicates the percentage reduction in the present value of spending arising from the tax in question.

To determine the value of B under the FairTax, we ran the program with all federal taxes turned off, and divided the present value of spending by 1.30 . Where does the 1.30 divisor come from? Well, 1.30 is the price of buying a dollar of real consumption under the FairTax inclusive of the sales tax. To see this, note that if the FairTax's retail sales tax rate is set at 30 percent, every dollar of income will yield 77 cents of consumption since $\$ 1.00$ divided by $\$ 1.30$ equals 77 cents. Of course, the fact that the $\$ 1.00$ of income is able to purchase 77 cents worth of consumption means that the income is effectively being taxed at a 23 percent rate.

\section{ESPlanner}


ESPlanner uses dynamic programming techniques to smooth a household's living standard over its life cycle to the extent possible without allowing the household to exceed its borrowing limit. In making its calculations, ESPlanner takes into account the non-fungible nature of housing, bequest plans, economies of shared living, the presence of children under age 19, and the desire of households to make "off-the-top" expenditures on college tuition, weddings, and other special expenses. In addition, ESPlanner simultaneously calculates the amounts of life insurance needed at each age by each spouse to guarantee that potential survivors suffer no decline in their living standards compared with what would otherwise be the case.

ESPlanner calculates time-paths of consumption expenditure, taxable saving, and term life insurance holdings in constant (2001) dollars. Consumption in this context is everything the household gets to spend after paying for its "off-the-top" expenditures - its housing expenses, special expenditures, life insurance premiums, special bequests, taxes, and net contributions to tax-favored accounts. Given the household's demographic information, preferences, and borrowing constraints, ESPlanner calculates the highest sustainable and smoothest possible living standard over time, leaving the household with zero terminal assets apart from the equity in homes that the user has chosen to not sell. The amount of recommended consumption expenditures needed to achieve a given living standard varies from year to year in response to changes in the household's composition. As indicated above, it also rises when the household moves from a situation of being liquidity constrained to one of being unconstrained. Finally, recommended household consumption will change over time if users intentionally specify, via the program's standard of living index, that they want their living standard to change.

ESPlanner's algorithm is complicated. But it's easy to check ESPlanner's reports to see that, given the inputs, preferences, and borrowing constraints, the program is recommending the highest and smoothest possible living standard that the household can sustain over time. And anyone can use the program to make the same and related tax rate calculations presented here.

Since the taxes paid by households depend on their total incomes, which include asset income, how much a household pays in taxes each year depends on how much it has consumed and saved in the past. But how much the household can consume and, therefore, how much it will save depends, in part, on how much it has to pay in taxes. Thus taxes depend on income and assets, which depend on taxes. This simultaneity means that the time-paths over the household's life cycle of consumption, saving, and tax payments must be jointly determined. ESPlanner achieves this simultaneous and consistent solution not only with respect to consumption and saving decisions, but also with respect to the purchase of life insurance. ${ }^{2}$

The solution method is iterative dynamic programming. ESPlanner has two dynamic programs that pass data to each other on an iterative basis until they both converge to a single mutually consistent solution to many decimal points of accuracy. The program begins its calculations with initial guesses of taxes, spending, life insurance holdings, and other variables and then updates these

\footnotetext{
${ }^{2}$ The program not only calculates the appropriate levels of life insurance at each age for each spouse when both are alive. It also determines how much life insurance each surviving spouse needs to purchase.
} 
variables in successive calculations that smooth the household's living standard through time and find the year-specific life insurance needed to preserve each year's calculated living standard.

Because taxes and Social Security benefits make a critical difference to how much a household should consume, save, and insure, casual calculation of these variables is a prescription for seriously misleading financial recommendations. ${ }^{3}$ As mentioned, ESPlanner has highly detailed federal income tax, state income tax, Social Security payroll tax, and Social Security benefit calculators. The federal and state income tax calculators determine whether the household should itemize its deductions, compute deductions and exemptions, deduct from taxable income contributions to taxdeferred retirement accounts, include in taxable income withdrawals from such accounts as well as the taxable component of Social Security benefits, and calculate total tax liabilities after all applicable refundable and nonrefundable tax credits.

These calculations are made separately for each year that the couple is alive as well as for each year a survivor may be alive. Moreover, ESPlanner's survivor tax and benefit calculations for surviving wives (husbands) are made separately for each possible date of death of the husband (wife), i.e., ESPlanner considers separately each date the husband (wife) might die and calculates the taxes and benefits a surviving wife (husband) would receive each year thereafter.

\section{The Stylized Households}

Our stylized households consist of either single individuals or married couples, whose spouses are the same age. We consider households age 30, 45, and 60. Both the single-headed households and the married households have two children to whom they gave birth at ages 27 and 29. Table 1 lists key assumptions about the seven single and seven married households we consider. The seven single households have initial labor earnings ranging from $\$ 10,000$ to $\$ 250,000$. For the seven married couples, the range is double that of the singles, i.e., from $\$ 20,000$ to $\$ 500,000$. All household heads and spouses retire at age 65 and start collecting Social Security benefits at age 66. Earnings between the household's current (2005) age and retirement are assumed to remain fixed in real terms.

Each household is assumed to have a home, a mortgage, and non-mortgage housing expenses. The 30-year-old households have initial assets equal to a quarter of a year's earnings. The older households are assumed to have the same assets that the 30-year-olds have accumulated by the age at which we consider the older households. Table 1 also shows our assumed annual college tuition and other expenses. The households pay these amounts each year for four years for each child when the child is age 19 to 22 .

\section{Treating Employer-Paid FICA Taxes and Corporate Income Taxes}

Since users enter their earnings net of employer-paid FICA taxes, ESPlanner does not explicitly

\footnotetext{
${ }^{3}$ See Gokhale, Jagadeesh, Laurence J. Kotlikoff, and Mark Warshawsky, "Comparing the Economic and Conventional Approaches to Financial Planning,” in Laurence J. Kotlikoff, Essays on Saving, Bequests, Altruism, and Life-Cycle Planning, Chicago, Ill.: University of Chicago Press, NBER volume, 2001, 489-560.
} 
calculate these taxes. Nor does it explicitly calculate corporate income taxes since users enter their expected returns net of such taxes.

From an economic perspective, employer-paid payroll taxes are no less of a burden or a work disincentive on workers than are those paid directly by employees. Indeed, there is only one economic difference between employer-paid and employee-paid payroll taxes; employer-paid payroll taxes are excludable from the calculation of adjusted gross income in determining federal personal income tax liability, whereas employee-paid payroll taxes are not.

In calculating marginal work taxes, the procedure for including the employer FICA tax is to (a) input into ESPlanner a given increase in current earnings, e.g., \$500, (b) iteratively and uniformly adjust the standard of living index values for 2006 and thereafter to ensure that the program's recommended consumption expenditure and standard of living for 2006 and thereafter remain unchanged, even though its recommended consumption and standard of living for 2005 rise, and (c) compare this so-derived increase in 2005 consumption spending, not with $\$ 500$, but rather with $\$ 500$ plus the additional FICA tax paid on $\$ 500$. This sum represents the full pre-tax compensation being paid to the household.

We used this same procedure in calculating average remaining lifetime tax rates under the current system; i.e., we first calculated for each stylized household its present value of spending under the current tax system and compared this present value with the present value of spending that would arise were the household to earn the same amount, but grossed up by the employer FICA tax. In determining employer-paid FICA taxes, we incorporated the fact that the OASDI portion of the FICA tax is paid only up to the covered earnings ceiling, while the HI FICA portion is paid on all FICA-eligible earnings.

Like employer-paid payroll taxes, corporate income taxes also reduce the return to input suppliers. But unlike payroll taxes, where the input supply is labor, the input supply relevant to the corporate income tax is household savings. These savings help finance corporations, and when corporations have to pay taxes, they can't pay as high a return to their investors. To capture this discrepancy between the pre- and post-corporate tax rates of return, we use the assumed 7.0 percent real return in all the discounting needed to determine marginal effective saving tax rates as well as average remaining lifetime tax rates. However, in actually running ESPlanner with federal taxes turned on, we enter the post-corporate return as an input in the program since, to repeat, ESPlanner doesn't calculate corporate taxes. On the other hand, in determining spending in the absence of any taxes, we enter the pre-corporate return in ESPlanner, since this is what savers would receive in a no-tax world.

\section{Findings}

Tables 2 through 5 present our findings. Table 2 compares the marginal effective tax rates on working under the current tax system with the 23 percent rate that would prevail under the FairTax. Except for single households with extremely low earnings, the marginal tax on work is higher, and often much higher, under the current system than under the FairTax. 
Take, as an example, a 45-year-old couple in which each spouse earns $\$ 50,000$. Each spouse faces a 33.7 percent marginal tax on an extra dollar earned, which is almost 50 percent higher than the 23 percent rate they would face under the FairTax. Since the efficiency cost of the distortion in work and other economic choices rises with the square of the tax levied on the choice, this stylized couple's welfare from the tax-induced distortion of its work/leisure choice is 2.15 times higher under today's tax system than it would be under the FairTax.

As a second example, consider the age 45 single household with $\$ 25,000$ in earnings. The current marginal work tax is 47.7 percent. This rate is more than twice the FairTax rate and engenders 4.3 times the amount of economic distortion. The reason this rate is so high is the fact that each dollar of earnings lowers the single individual's Earned Income Tax Credit by roughly 22 cents. Add that to a 10 percent federal tax rate and 15.3 percent payroll tax rate, and you can quickly see that our calculation of a rate this high is no mistake. ${ }^{4}$

The Earned Income Tax Credit (EITC) explains the negative effective tax rate on working for single households earning $\$ 10,000$ or less. By the time the single household reaches age 60 , he or she can no longer receive the credit because his or her asset income exceeds the eligibility limit. And his or her marginal tax rate is a positive 29.8 percent.

The striking pattern in Table 2 is that, under our current tax system, there is no pattern - or at least no monotonic pattern - connecting the size of marginal tax rates on working with the level of earnings. Take 45-year-old married couples. When total household earnings equal $\$ 20,000$ per year (in today’s dollars), the marginal work tax rate is 41.4 percent. This rises to 47.6 percent at $\$ 30,000$ of earnings, falls to 28.2 percent at $\$ 70,000$ of earnings, and then rises to 38.4 percent at $\$ 500,000$ of earnings. There is also no clear pattern by age of these marginal wage tax rates. For some earnings levels, the marginal tax rate rises with age. For other levels, it falls with age.

\section{Marginal Tax Rates on Saving}

In addition to generating higher and, often much higher, work disincentives than the FairTax, the current tax system embeds very significant saving disincentives. In contrast, the FairTax generates no saving disincentives whatsoever. As Table 3 shows, the effective tax rate levied on saving under the current system, as measured here, ranges from a low of 23.1 percent to a high of 43.0 percent for single households and from a low of 22.6 percent to a high of 54.2 percent for married households.

Unlike the wage tax rates of Table 2, marginal saving tax rates are almost always higher at higher levels of earnings. And they generally decline with age, holding the level of earnings fixed. The former pattern simply reflects the fact that higher incomes put households in higher federal income

\footnotetext{
${ }^{4}$ One cannot strictly add these rates together because the employer's FICA contribution is an exclusion from the federal personal tax, because earning more at age 45 affects future Social Security benefits as well as taxation of those benefits, and because there are a variety of features in the personal income tax (including tax credits, the alternative minimum tax, and the claw back of itemized deductions at high levels of adjusted gross income) that influence a taxpayer's effective tax bracket.
} 
tax brackets. The latter pattern reflects the fact that older households have relatively few years over which to spend their saving and, therefore, relatively few years over which to lose what would otherwise be a much higher real return to saving.

Table 4 examines the marginal saving tax rates of Table 3 with one change in assumption, namely that all saving is invested in assets whose return comes either in the form of a capital gain or a dividend. The income from such assets is taxed at most at a 15 percent rate. The ability to pay capital income taxes at a lower rate explains why the saving tax rates under the current system are lower, particularly for upper income earnings, than they are in Table 3. Nevertheless, there is still a huge saving tax so there would be a huge reduction in the disincentive to save from switching to the FairTax.

\section{Average Remaining Lifetime Tax Rates}

Table 5 presents our calculation of average remaining lifetime tax rates, both those now prevailing and those that would prevail under the FairTax. To repeat, these tax rates net out Social Security benefits as well as the FairTax rebate. In the case of the FairTax, the Social Security benefits are adjusted upward to maintain the real purchasing power of the benefits.

A glance at the table indicates that the FairTax entails either a significant or a substantial reduction in the remaining lifetime tax rates of all of our stylized households. For example, the stylized single age 45 household with $\$ 35,000$ in annual income pays, on average, 20.7 percent of its remaining lifetime resources to the government under our current tax system, but only 5.4 percent under the FairTax. The same aged married couple in which both spouses earn $\$ 35,000$ faces a 21.3 percent current average tax rate, but only an 11.6 percent average tax rate under the FairTax.

For older, low-income households, the FairTax generates a major reduction in remaining lifetime taxes. Again, the reason is that the elderly not only continue, under the FairTax, to receive the same real Social Security benefits, they also receive the FairTax rebate. Take a single 60 -year-old earning $\$ 15,000$ a year. His or her average remaining lifetime tax rate falls from 9.8 percent to -28.0 percent!

The FairTax not only lowers remaining average lifetime net tax rates. It also maintains and, indeed, enhances overall progressivity in the tax system. Consider middle-aged married households. The FairTax average lifetime tax rate is very low - only 1.5 percent - for the couple with $\$ 20,000$ in annual earnings, and much higher - 20.5 percent - for the couple with $\$ 500,000$ in annual earnings. The reduction in the tax rate at low earnings is proportionately much greater at the low end of the earnings distribution than at the high end. In switching to the FairTax, the $\$ 20,000$-earning couple experiences an 86 percent cut in its average tax rate, whereas the $\$ 500,000$-earning couple experiences a 42 percent cut.

\section{Conclusion}

Most commentators, including Gale (2005), have considered the FairTax in a vacuum, i.e., without 
comparing its marginal and average tax rates with the combined marginal and average tax rates implicit in our current system. Compared with our existing federal tax system, the FairTax, as proposed in H.R. 25/S. 25, would significantly reduce marginal taxes on work, dramatically reduce marginal taxes on saving, and substantially lower overall tax burdens on current and future workers. Moreover, it would do this without limiting tax progressivity. Indeed, the FairTax would make our tax system more progressive. 


\section{Reference}

Auerbach, Alan J. and Laurence J. Kotlikoff, Dynamic Fiscal Policy, Cambridge, England: Cambridge University Press, 1987.

Bachman, Paul, Jonathan Haughton, Laurence J. Kotlikoff, Alfonso Sanchez-Penalver, and David G. Tuerck, “Taxing Sales Under the FairTax - What Rate Works?” Beacon Hill Associates of Suffolk University, March 2006.

Gale, William G., “The National Retail Sales Tax: What Would the Rate Have to Be?” Tax Notes, May 16, 2005.

Gokhale, Jagadeesh, Laurence J. Kotlikoff, and John Sabelhaus, "Understanding the Postwar Decline in U.S. Saving,” The Brookings Papers on Economic Activity, 1996.

Gokhale, Jagadeesh, Laurence J. Kotlikoff, and Alexi Sluchynsky, “Does It Pay to Work,” NBER Working Paper no. 9096, August 2002.

Gokhale, Jagadeesh, Laurence J. Kotlikoff, and Mark Warshawsky, “Comparing the Economic and Conventional Approaches to Financial Planning,” in Laurence J. Kotlikoff, Essays on Saving, Bequests, Altruism, and Life-Cycle Planning, Chicago, Ill.: University of Chicago Press, NBER volume, 2001, 489-560.

Kotlikoff, Laurence J. and Sabine Jokisch, "Simulating the Dynamic Macroeconomic and Microeconomic Effects of the FairTax,” NBER Working Paper no. 11858, Cambridge MA, (December 2005).

Summers, Lawrence H., "Capital Taxation and Accumulation in a Life-Cycle Model,” American Economic Review, 71(4), September 1981.

U.S. Government Accountability Office, "Summary of Estimates of the Costs of the Federal Tax System,” August 2005. 
Table 1

\section{Profiles of Stylized Households}

\begin{tabular}{|c|c|c|c|c|c|c|c|}
\hline \multicolumn{8}{|c|}{ Single Households } \\
\hline $\begin{array}{l}\text { Total } \\
\text { Household } \\
\text { Income }\end{array}$ & $\begin{array}{l}\text { Assets at } \\
\text { Age } 30\end{array}$ & $\begin{array}{l}\text { Annual } \\
\text { College } \\
\text { Expense }\end{array}$ & $\begin{array}{l}\text { House } \\
\text { Value }\end{array}$ & Mortgage & $\begin{array}{c}\text { Monthly } \\
\text { Mortgage } \\
\text { Payment }\end{array}$ & $\begin{array}{l}\text { Annual } \\
\text { Property } \\
\text { Taxes }\end{array}$ & $\begin{array}{l}\text { Annual Home } \\
\text { Maintenance }\end{array}$ \\
\hline$\$ 10,000$ & $\$ 2,500$ & $\$ 2,500$ & $\$ 20,000$ & $\$ 16,000$ & $\$ 200$ & $\$ 200$ & $\$ 67$ \\
\hline$\$ 15,000$ & $\$ 3,750$ & $\$ 3,750$ & $\$ 30,000$ & $\$ 24,000$ & $\$ 300$ & $\$ 300$ & $\$ 100$ \\
\hline$\$ 25,000$ & $\$ 6,250$ & $\$ 5,000$ & $\$ 50,000$ & $\$ 40,000$ & $\$ 500$ & $\$ 500$ & $\$ 167$ \\
\hline$\$ 35,000$ & $\$ 8,750$ & $\$ 7,000$ & $\$ 70,000$ & $\$ 56,000$ & $\$ 700$ & $\$ 700$ & $\$ 234$ \\
\hline$\$ 50,000$ & $\$ 12,500$ & $\$ 10,000$ & $\$ 100,000$ & $\$ 80,000$ & $\$ 1,000$ & $\$ 1,000$ & $\$ 333$ \\
\hline$\$ 100,000$ & $\$ 25,000$ & $\$ 20,000$ & $\$ 200,000$ & $\$ 160,000$ & $\$ 2,000$ & $\$ 2,000$ & $\$ 666$ \\
\hline$\$ 250,000$ & $\$ 62,500$ & $\$ 20,000$ & $\$ 500,000$ & $\$ 400,000$ & $\$ 5,000$ & $\$ 5,000$ & $\$ 1,667$ \\
\hline \multicolumn{8}{|c|}{ Married Households } \\
\hline $\begin{array}{c}\text { Total } \\
\text { Household } \\
\text { Income }\end{array}$ & $\begin{array}{c}\text { Assets at } \\
\text { Age } 30\end{array}$ & $\begin{array}{l}\text { Annual } \\
\text { College } \\
\text { Expense }\end{array}$ & $\begin{array}{l}\text { House } \\
\text { Value }\end{array}$ & Mortgage & $\begin{array}{c}\text { Monthly } \\
\text { Mortgage } \\
\text { Payment }\end{array}$ & $\begin{array}{c}\text { Annual } \\
\text { Property } \\
\text { Taxes }\end{array}$ & $\begin{array}{c}\text { Annual } \\
\text { Home } \\
\text { Maintenance }\end{array}$ \\
\hline$\$ 20,000$ & $\$ 5,000$ & $\$ 5,000$ & $\$ 40,000$ & $\$ 32,000$ & $\$ 400$ & $\$ 400$ & $\$ 133$ \\
\hline$\$ 30,000$ & $\$ 7,500$ & $\$ 7,500$ & $\$ 60,000$ & $\$ 48,000$ & $\$ 600$ & $\$ 600$ & $\$ 200$ \\
\hline$\$ 50,000$ & $\$ 12,500$ & $\$ 10,000$ & $\$ 100,000$ & $\$ 80,000$ & $\$ 1,000$ & $\$ 1,000$ & $\$ 333$ \\
\hline$\$ 70,000$ & $\$ 24,500$ & $\$ 14,000$ & $\$ 140,000$ & $\$ 136,000$ & $\$ 1,400$ & $\$ 1,400$ & $\$ 466$ \\
\hline$\$ 100,000$ & $\$ 25,000$ & $\$ 20,000$ & $\$ 200,000$ & $\$ 160,000$ & $\$ 2,000$ & $\$ 2,000$ & $\$ 667$ \\
\hline$\$ 200,000$ & $\$ 50,000$ & $\$ 40,000$ & $\$ 400,000$ & $\$ 320,000$ & $\$ 4,000$ & $\$ 4,000$ & $\$ 1,334$ \\
\hline$\$ 500,000$ & $\$ 125,000$ & $\$ 40,000$ & $\$ 1,000,000$ & $\$ 800,000$ & $\$ 10,000$ & $\$ 10,000$ & $\$ 3,333$ \\
\hline
\end{tabular}


Table 2

Marginal Effective Federal Tax Rates on Working

\begin{tabular}{|c|c|c|c|c|c|c|}
\hline \multicolumn{7}{|c|}{ Single Households } \\
\hline \multirow{2}{*}{$\begin{array}{l}\text { Total } \\
\text { Household } \\
\text { Income }\end{array}$} & \multicolumn{2}{|c|}{$\begin{array}{c}\text { Young Adult } \\
\text { (Age 30) }\end{array}$} & \multicolumn{2}{|c|}{$\begin{array}{c}\text { Middle Aged } \\
\text { (Age 45) }\end{array}$} & \multicolumn{2}{|c|}{$\begin{array}{c}\text { Senior } \\
\text { (Age 60) }\end{array}$} \\
\hline & $\begin{array}{l}\text { Current } \\
\text { System }\end{array}$ & FairTax & $\begin{array}{l}\text { Current } \\
\text { System }\end{array}$ & FairTax & $\begin{array}{l}\text { Current } \\
\text { System }\end{array}$ & FairTax \\
\hline$\$ 10,000$ & $-23.1 \%$ & $23.0 \%$ & $-23.2 \%$ & $23.0 \%$ & $29.8 \%$ & $23.0 \%$ \\
\hline$\$ 15,000$ & $33.3 \%$ & $23.0 \%$ & $33.8 \%$ & $23.0 \%$ & $22.4 \%$ & $23.0 \%$ \\
\hline$\$ 25,000$ & $34.2 \%$ & $23.0 \%$ & $47.7 \%$ & $23.0 \%$ & $26.2 \%$ & $23.0 \%$ \\
\hline$\$ 35,000$ & $50.2 \%$ & $23.0 \%$ & $28.3 \%$ & $23.0 \%$ & $29.0 \%$ & $23.0 \%$ \\
\hline$\$ 50,000$ & $28.2 \%$ & $23.0 \%$ & $22.4 \%$ & $23.0 \%$ & $36.5 \%$ & $23.0 \%$ \\
\hline$\$ 100,000$ & $27.6 \%$ & $23.0 \%$ & $27.5 \%$ & $23.0 \%$ & $28.6 \%$ & $23.0 \%$ \\
\hline$\$ 250,000$ & $41.5 \%$ & $23.0 \%$ & $37.2 \%$ & $23.0 \%$ & $35.5 \%$ & $23.0 \%$ \\
\hline \multicolumn{7}{|c|}{ Married Households } \\
\hline \multirow{2}{*}{$\begin{array}{l}\text { Total } \\
\text { Household } \\
\text { Income }\end{array}$} & \multicolumn{2}{|c|}{$\begin{array}{l}\text { Young Adult } \\
\text { (Age 30) }\end{array}$} & \multicolumn{2}{|c|}{$\begin{array}{l}\text { Middle Aged } \\
\quad \text { (Age 45) }\end{array}$} & \multicolumn{2}{|c|}{$\begin{array}{c}\text { Senior } \\
\text { (Age 60) }\end{array}$} \\
\hline & $\begin{array}{l}\text { Current } \\
\text { System }\end{array}$ & FairTax & $\begin{array}{l}\text { Current } \\
\text { System }\end{array}$ & FairTax & $\begin{array}{l}\text { Current } \\
\text { System }\end{array}$ & FairTax \\
\hline$\$ 20,000$ & $33.8 \%$ & $23.0 \%$ & $41.4 \%$ & $23.0 \%$ & $23.5 \%$ & $23.0 \%$ \\
\hline$\$ 30,000$ & $33.7 \%$ & $23.0 \%$ & $47.6 \%$ & $23.0 \%$ & $28.2 \%$ & $23.0 \%$ \\
\hline$\$ 50,000$ & $28.0 \%$ & $23.0 \%$ & $28.2 \%$ & $23.0 \%$ & $28.2 \%$ & $23.0 \%$ \\
\hline$\$ 70,000$ & $28.3 \%$ & $23.0 \%$ & $28.2 \%$ & $23.0 \%$ & $32.7 \%$ & $23.0 \%$ \\
\hline$\$ 100,000$ & $33.5 \%$ & $23.0 \%$ & $33.7 \%$ & $23.0 \%$ & $34.3 \%$ & $23.0 \%$ \\
\hline$\$ 200,000$ & $35.3 \%$ & $23.0 \%$ & $31.2 \%$ & $23.0 \%$ & $37.5 \%$ & $23.0 \%$ \\
\hline$\$ 500,000$ & $38.4 \%$ & $23.0 \%$ & $38.4 \%$ & $23.0 \%$ & $37.2 \%$ & $23.0 \%$ \\
\hline
\end{tabular}


Table 3

Marginal Effective Federal Tax Rates on Saving

\begin{tabular}{|c|c|c|c|c|c|c|}
\hline \multicolumn{7}{|c|}{ Single Households } \\
\hline \multirow{2}{*}{$\begin{array}{l}\text { Total } \\
\text { Household } \\
\text { Income }\end{array}$} & \multicolumn{2}{|c|}{$\begin{array}{c}\text { Young Adult } \\
\text { (Age 30) }\end{array}$} & \multicolumn{2}{|c|}{$\begin{array}{c}\text { Middle Aged } \\
\text { (Age 45) }\end{array}$} & \multicolumn{2}{|c|}{$\begin{array}{c}\begin{array}{c}\text { Senior } \\
(\text { Age 60) }\end{array} \\
\end{array}$} \\
\hline & $\begin{array}{l}\text { Current } \\
\text { System }\end{array}$ & FairTax & $\begin{array}{l}\text { Current } \\
\text { System }\end{array}$ & FairTax & $\begin{array}{l}\text { Current } \\
\text { System }\end{array}$ & FairTax \\
\hline$\$ 10,000$ & $24.6 \%$ & $0.0 \%$ & $25.2 \%$ & $0.0 \%$ & $24.8 \%$ & $0.0 \%$ \\
\hline$\$ 15,000$ & $24.6 \%$ & $0.0 \%$ & $26.2 \%$ & $0.0 \%$ & $23.1 \%$ & $0.0 \%$ \\
\hline$\$ 25,000$ & $24.7 \%$ & $0.0 \%$ & $27.2 \%$ & $0.0 \%$ & $23.2 \%$ & $0.0 \%$ \\
\hline$\$ 35,000$ & $25.2 \%$ & $0.0 \%$ & $27.3 \%$ & $0.0 \%$ & $26.4 \%$ & $0.0 \%$ \\
\hline$\$ 50,000$ & $25.3 \%$ & $0.0 \%$ & $31.3 \%$ & $0.0 \%$ & $32.4 \%$ & $0.0 \%$ \\
\hline$\$ 100,000$ & $30.2 \%$ & $0.0 \%$ & $34.8 \%$ & $0.0 \%$ & $39.2 \%$ & $0.0 \%$ \\
\hline$\$ 250,000$ & $36.0 \%$ & $0.0 \%$ & $43.0 \%$ & $0.0 \%$ & $37.2 \%$ & $0.0 \%$ \\
\hline \multicolumn{7}{|c|}{ Married Households } \\
\hline \multirow{2}{*}{$\begin{array}{l}\text { Total } \\
\text { Household } \\
\text { Income }\end{array}$} & \multicolumn{2}{|c|}{$\begin{array}{c}\text { Young Adult } \\
\text { (Age 30) }\end{array}$} & \multicolumn{2}{|c|}{$\begin{array}{c}\text { Middle Aged } \\
(\text { Age 45) }\end{array}$} & \multicolumn{2}{|c|}{$\begin{array}{c}\text { Senior } \\
(\text { Age 60) }\end{array}$} \\
\hline & $\begin{array}{l}\text { Current } \\
\text { System }\end{array}$ & FairTax & $\begin{array}{l}\text { Current } \\
\text { System }\end{array}$ & FairTax & $\begin{array}{l}\text { Current } \\
\text { System }\end{array}$ & FairTax \\
\hline$\$ 20,000$ & $26.5 \%$ & $0.0 \%$ & $27.2 \%$ & $0.0 \%$ & $22.6 \%$ & $0.0 \%$ \\
\hline$\$ 30,000$ & $26.6 \%$ & $0.0 \%$ & $27.1 \%$ & $0.0 \%$ & $23.6 \%$ & $0.0 \%$ \\
\hline$\$ 50,000$ & $29.0 \%$ & $0.0 \%$ & $27.5 \%$ & $0.0 \%$ & $23.6 \%$ & $0.0 \%$ \\
\hline$\$ 70,000$ & $28.9 \%$ & $0.0 \%$ & $30.5 \%$ & $0.0 \%$ & $32.2 \%$ & $0.0 \%$ \\
\hline$\$ 100,000$ & $33.4 \%$ & $0.0 \%$ & $33.8 \%$ & $0.0 \%$ & $36.4 \%$ & $0.0 \%$ \\
\hline$\$ 200,000$ & $37.3 \%$ & $0.0 \%$ & $39.4 \%$ & $0.0 \%$ & $35.2 \%$ & $0.0 \%$ \\
\hline$\$ 500,000$ & $54.2 \%$ & $0.0 \%$ & $50.7 \%$ & $0.0 \%$ & $38.2 \%$ & $0.0 \%$ \\
\hline
\end{tabular}


Table 4

Marginal Effective Federal Tax Rates on Saving Assuming Return is Taxed at Capital Gains/Dividend Rate

\begin{tabular}{|c|c|c|c|c|c|c|}
\hline \multicolumn{7}{|c|}{ Single Households } \\
\hline \multirow{2}{*}{$\begin{array}{c}\text { Total } \\
\text { Household } \\
\text { Income }\end{array}$} & \multicolumn{2}{|c|}{$\begin{array}{l}\text { Young Adult } \\
\text { (Age 30) }\end{array}$} & \multicolumn{2}{|c|}{$\begin{array}{l}\text { Middle Aged } \\
\text { (Age 45) }\end{array}$} & \multicolumn{2}{|c|}{$\begin{array}{c}\text { Senior } \\
\text { (Age 60) }\end{array}$} \\
\hline & $\begin{array}{l}\text { Current } \\
\text { System }\end{array}$ & FairTax & $\begin{array}{l}\text { Current } \\
\text { System }\end{array}$ & FairTax & $\begin{array}{l}\text { Current } \\
\text { System }\end{array}$ & FairTax \\
\hline$\$ 10,000$ & $24.6 \%$ & $0.0 \%$ & $25.0 \%$ & $0.0 \%$ & $21.5 \%$ & $0.0 \%$ \\
\hline$\$ 15,000$ & $24.6 \%$ & $0.0 \%$ & $25.1 \%$ & $0.0 \%$ & $20.7 \%$ & $0.0 \%$ \\
\hline$\$ 25,000$ & $24.7 \%$ & $0.0 \%$ & $26.5 \%$ & $0.0 \%$ & $20.1 \%$ & $0.0 \%$ \\
\hline$\$ 35,000$ & $25.2 \%$ & $0.0 \%$ & $26.9 \%$ & $0.0 \%$ & $24.0 \%$ & $0.0 \%$ \\
\hline$\$ 50,000$ & $25.3 \%$ & $0.0 \%$ & $27.8 \%$ & $0.0 \%$ & $23.9 \%$ & $0.0 \%$ \\
\hline$\$ 100,000$ & $28.8 \%$ & $0.0 \%$ & $33.8 \%$ & $0.0 \%$ & $38.1 \%$ & $0.0 \%$ \\
\hline$\$ 250,000$ & $30.4 \%$ & $0.0 \%$ & $33.7 \%$ & $0.0 \%$ & $26.9 \%$ & $0.0 \%$ \\
\hline \multicolumn{7}{|c|}{ Married Households } \\
\hline \multirow{2}{*}{$\begin{array}{c}\text { Total } \\
\text { Household } \\
\text { Income }\end{array}$} & \multicolumn{2}{|c|}{$\begin{array}{c}\text { Young Adult } \\
\text { (Age 30) }\end{array}$} & \multicolumn{2}{|c|}{$\begin{array}{c}\begin{array}{c}\text { Middle Aged } \\
\text { (Age 45) }\end{array} \\
\end{array}$} & \multicolumn{2}{|c|}{$\begin{array}{c}\text { Senior } \\
\text { (Age 60) }\end{array}$} \\
\hline & $\begin{array}{l}\text { Current } \\
\text { System }\end{array}$ & FairTax & $\begin{array}{l}\text { Current } \\
\text { System }\end{array}$ & FairTax & $\begin{array}{l}\text { Current } \\
\text { System }\end{array}$ & FairTax \\
\hline$\$ 20,000$ & $26.3 \%$ & $0.0 \%$ & $25.9 \%$ & $0.0 \%$ & $21.3 \%$ & $0.0 \%$ \\
\hline$\$ 30,000$ & $26.9 \%$ & $0.0 \%$ & $26.1 \%$ & $0.0 \%$ & $21.4 \%$ & $0.0 \%$ \\
\hline$\$ 50,000$ & $27.3 \%$ & $0.0 \%$ & $26.5 \%$ & $0.0 \%$ & $21.1 \%$ & $0.0 \%$ \\
\hline$\$ 70,000$ & $27.8 \%$ & $0.0 \%$ & $27.2 \%$ & $0.0 \%$ & $23.7 \%$ & $0.0 \%$ \\
\hline$\$ 100,000$ & $31.9 \%$ & $0.0 \%$ & $29.2 \%$ & $0.0 \%$ & $27.6 \%$ & $0.0 \%$ \\
\hline$\$ 200,000$ & $32.9 \%$ & $0.0 \%$ & $34.1 \%$ & $0.0 \%$ & $29.7 \%$ & $0.0 \%$ \\
\hline$\$ 500,000$ & $39.8 \%$ & $0.0 \%$ & $38.3 \%$ & $0.0 \%$ & $29.8 \%$ & $0.0 \%$ \\
\hline
\end{tabular}


Table 5

Average Remaining Federal Lifetime Tax Rates

- the Current System vs. the FairTax

\begin{tabular}{|c|c|c|c|c|c|c|}
\hline \multicolumn{7}{|c|}{ Single Households } \\
\hline \multirow{2}{*}{$\begin{array}{c}\text { Total } \\
\text { Household } \\
\text { Income }\end{array}$} & \multicolumn{2}{|c|}{$\begin{array}{l}\text { Young Adult } \\
\text { (Age 30) }\end{array}$} & \multicolumn{2}{|c|}{$\begin{array}{l}\text { Middle Aged } \\
\quad \text { (Age 45) }\end{array}$} & \multicolumn{2}{|c|}{$\begin{array}{c}\text { Senior } \\
\text { (Age 60) }\end{array}$} \\
\hline & $\begin{array}{l}\text { Current } \\
\text { System }\end{array}$ & FairTax & $\begin{array}{l}\text { Current } \\
\text { System }\end{array}$ & FairTax & $\begin{array}{l}\text { Current } \\
\text { System }\end{array}$ & FairTax \\
\hline$\$ 10,000$ & $-12.3 \%$ & $-7.3 \%$ & $6.2 \%$ & $-4.2 \%$ & $6.5 \%$ & $-19.6 \%$ \\
\hline$\$ 15,000$ & $-4.0 \%$ & $2.3 \%$ & $11.3 \%$ & $-0.8 \%$ & $9.8 \%$ & $-19.2 \%$ \\
\hline$\$ 25,000$ & $10.2 \%$ & $10.2 \%$ & $17.7 \%$ & $9.9 \%$ & $14.1 \%$ & $-2.6 \%$ \\
\hline$\$ 35,000$ & $18.5 \%$ & $13.6 \%$ & $20.7 \%$ & $10.8 \%$ & $16.7 \%$ & $-1.8 \%$ \\
\hline$\$ 50,000$ & $21.1 \%$ & $16.2 \%$ & $23.5 \%$ & $15.2 \%$ & $21.5 \%$ & $5.8 \%$ \\
\hline$\$ 100,000$ & $27.5 \%$ & $19.4 \%$ & $30.3 \%$ & $17.7 \%$ & $32.1 \%$ & $10.9 \%$ \\
\hline$\$ 250,000$ & $27.9 \%$ & $21.5 \%$ & $33.6 \%$ & $21.0 \%$ & $40.8 \%$ & $18.7 \%$ \\
\hline \multicolumn{7}{|c|}{ Married Households } \\
\hline \multirow{2}{*}{$\begin{array}{l}\text { Total } \\
\text { Household } \\
\text { Income }\end{array}$} & \multicolumn{2}{|c|}{$\begin{array}{c}\text { Young Adult } \\
\text { (Age 30) }\end{array}$} & \multicolumn{2}{|c|}{$\begin{array}{l}\text { Middle Aged } \\
\quad \text { (Age 45) }\end{array}$} & \multicolumn{2}{|c|}{$\begin{array}{c}\text { Senior } \\
\text { (Aqe 60) }\end{array}$} \\
\hline & $\begin{array}{l}\text { Current } \\
\text { System }\end{array}$ & FairTax & $\begin{array}{l}\text { Current } \\
\text { System }\end{array}$ & FairTax & $\begin{array}{l}\text { Current } \\
\text { System }\end{array}$ & FairTax \\
\hline$\$ 20,000$ & $3.1 \%$ & $7.0 \%$ & $11.0 \%$ & $7.3 \%$ & $7.2 \%$ & $-7.2 \%$ \\
\hline$\$ 30,000$ & $12.5 \%$ & $11.9 \%$ & $15.3 \%$ & $9.3 \%$ & $10.1 \%$ & $-6.1 \%$ \\
\hline$\$ 50,000$ & $19.1 \%$ & $16.0 \%$ & $19.6 \%$ & $14.8 \%$ & $14.2 \%$ & $3.2 \%$ \\
\hline$\$ 70,000$ & $21.1 \%$ & $17.8 \%$ & $21.3 \%$ & $15.5 \%$ & $17.0 \%$ & $4.3 \%$ \\
\hline$\$ 100,000$ & $23.2 \%$ & $19.1 \%$ & $24.0 \%$ & $17.7 \%$ & $22.4 \%$ & $8.9 \%$ \\
\hline$\$ 200,000$ & $27.2 \%$ & $20.8 \%$ & $29.0 \%$ & $19.4 \%$ & $32.2 \%$ & $13.2 \%$ \\
\hline$\$ 500,000$ & $30.6 \%$ & $22.1 \%$ & $35.6 \%$ & $21.6 \%$ & $41.5 \%$ & $19.5 \%$ \\
\hline
\end{tabular}

